\title{
The Role of Halal Living on Muslim Millennial in Applying Halal Lifestyle
}

\author{
1 Fitri Sarasati \\ 1Universitas Satya Negara, Indonesia \\ fitrisarasati@gmail.com
}

\begin{tabular}{|c|c|}
\hline Article Info & Abstract \\
\hline $\begin{array}{l}\text { Article History } \\
\text { Received: July 12, } 2018 \\
\text { Accepted: September 30, } \\
2018\end{array}$ & \multirow[b]{2}{*}{$\begin{array}{l}\text { Halal has currently become lifestyle and trend that spread out in the } \\
\text { community. Realizing the new tendency, NetTV as one of the media } \\
\text { industries in Indonesia presents a program called Halal Living. The program } \\
\text { contains information about travel, halal culinary, fashion hijab, health and } \\
\text { beauty closely related to the life of Muslim women. An impression is expected } \\
\text { to spread a positive and acceptable message by the public. According to the } \\
\text { Stimulus-Organism-Response ( } S \text { - } O \text {-R) theory, humans will produce certain } \\
\text { behaviors if there is a certain stimulus; thus, the effect is a reaction to the } \\
\text { stimulus. Stimulus in this research is the message delivered in program; the } \\
\text { organism an informant who is a Muslim millennial; while the response } \\
\text { awareness of halal lifestyle. In this research, halal living impressions will be } \\
\text { seen from knowledge, attitude, and motivation of the informant. Informant's } \\
\text { knowledge concerns the informant's understanding about the impressions } \\
\text { and messages presented. Informant's attitudes deal with likes or dislikes } \\
\text { regarding the impressions and messages presented. Motivation of informant } \\
\text { concerns the desire of informants to apply the message or information } \\
\text { delivered throughout the program. This study aimed to analyze the role of } \\
\text { halal living show on Muslim millennial in applying halal life. It used } \\
\text { qualitative descriptive approach. The data were collected using observation } \\
\text { and semi-structured interview with Muslim millennial born in 1980-1995. } \\
\text { The results reveal that Muslim millennial are interested in watching halal } \\
\text { living program because the values it contains is well-packaged; the host is } \\
\text { the hijaber, who is an Indonesian Muslim influencer; and messages it delivers } \\
\text { are applicable and effective. }\end{array}$} \\
\hline $\begin{array}{l}\text { Keywords } \\
\text { Halal; Life Style; Muslim; } \\
\text { Program. }\end{array}$ & \\
\hline $\begin{array}{l}\text { Support by: } \\
\text { doi Crossref }\end{array}$ & This is an open access article under the CC-BY-SA license \\
\hline
\end{tabular}

\section{INTRODUCTION}

Indonesia is a country with the largest Muslim population in the world. The large number of Muslim population in Indonesia is certainly open opportunities for business and industrial sector to capture the market through halal products. According to Euromonitor International, global market research company earning halal products in five countries with the largest Muslim population, such as Indonesia, Pakistan, India, Nigeria, Iran has grown by 257 (\%) percent. Nowadays halal is not just a rule in Islamic law, but also a way of life. Halal Lifestyle can be applied into various sectors such as food, fashion trend, cosmetic, education, financial, pharmaceutical, media and recreation, healthcare and wellness. Realizing the trend of Halal Lifestyle in society, Net TV as one of the media industry in Indonesia presents Halal Living. Halal Living is an existing segment of the Indonesia Morning Show (IMS) program that carries the theme of tourism, halal culinary, health, fashion hijab, social movement and beauty.

The Host of Halal Living is hijaber such as Hamidah Rachmayanti, Bella Atamimi, Aghnia Punjabi, and Gita Savitri. The Hosts are the Indonesian Hijabers who are also 
Muslimah Influencer Indonesia. As the Host of Halal Living they are expected to represent Muslim millennial to remain fashionable and active with hijab. Halal Living invites people to explore the natural beauty and cultural richness of Indonesia with Islamic nuances. Halal Living provides complete information on tourist destinations, halal culinary, holiday tips, beauty tips, and various things related to halal lifestyle needed by Muslim millennial.

Muslim millennial in this research is $\mathrm{Y}$ generation born in 1980-1995. Muslim millennial has better ability to access communication and information technology than previous generations. So the internet becomes an option to seek a variety of information and communication. Net TV presents Halal Living as a choice of impressions that not only provide entertainment but also still can spread the values of Islam to the community, especially Muslim millennial. Halal Living can not only be watched through television media but can also be watched through YouTube so that people can watch halal living anytime and anywhere this study aims to analyze the role of halal living on Muslim Millennial in Applying Halal Lifestyle.

\section{METHOD}

This research uses qualitative research type with descriptive analysis level. The purpose of this research is to make a systematic, factual, and accurate description of the facts and properties of a particular population or object. Methods of data collection include: (1) Observation of non-participant, researchers only act to observe or observe without participate in activities such as the group or subject studied (Kriyantono, 2010). Observations that researchers do is to observe the live halal impressions that are broadcast on Net TV or YouTube. Halal Living episodes are observed: a. Lombok's natural and cultural charm, b. Bali Friendly Muslim Tour, c. Islamic Light in Tanah Sumba, d. Building Ambon Through Heka Leka, and e.Halal Tours of The City of Thousand Churches; (2) Semi-structured interviews, according to Kriyantono (2010), in semi-structured interviews usually interviewers have a list of questions written but it is possible to ask questions related to research problems. Researchers conducted interviews with five Muslim women who had watched halal living.

\section{RESULT}

Based on the results of interviews conducted it is known that they often watch halal living not only through the channel Net TV but also through YouTube. According to informants the content presented in halal living make them more familiar with the city in Indonesia. In the halal living episode the natural and cultural charm of Lombok, viewers is invited to see the natural wealth of Bayan Village, which is located in Bayan District, North Lombok. The entry of Islam on Lombok Island was first in Bayan Village. There is an ancient Mosque of Bayan Belek which became a tourist attraction in Bayan Village. Ancient Mosque Bayan Belek is different from the mosque in general. The uniqueness of this mosque lies in its walls made of bamboo and its grounded floors give a strong traditional impression. In addition to the Ancient Bayan Mosque one of the interesting tourism potential is the woven fabric of Bayan. The fabric can then be combined with matching hijab and clothing that can be worn to various events.

According to Wenny (30), after watching the halal living edition of Nature charm and cultural richness of Lombok she became understand how the history of the entry of Islam on the island of Lombok. This episode also provides information about the weaving of Bayan which is the arts and crafts typical of the Bayan community. Wenny 
became interested in using woven fabrics to attend official events. She also wanted to have tenun Bayan that has attractive colors to add to the collection of formal clothing that she has. Based on the results of these interviews can be seen that the knowledge of Wenny became increased after watching the halal living episodes of natural charm and wealth of the island of Lombok. Initially Wenny only knew that Lombok is a famous tourist destination with beach tourism and known as city with thousand mosques. After watching halal living Wenny became aware of how the process of entry of Islam in Lombok Island. In addition, Wenny also likes the typical weaving of Bayan.

In addition to episode about the natural charm and culture of Lombok, another episode analyzed in this research is the episode of Bali Muslim Friendly Tour. The episode made Muslim women understand that although the majority of Bali's population is Hindu but they still maintain religious tolerance. For Muslim women who want to travel to Bali do not have to worry because in Bali has been in many mosque and also halal culinary. The Balinese are also open to the arrival of Muslim tourists. As the result of an interview with one informant named Detti (26), "Watching halal living makes me know that in Puja Mandala Nusa Dua area stand five places of worship. Great Mosque of Ibnu Battuta became a magnificent mosque that we can use to worship during the visit to Nusa Dua. In Bali there is also many places to eat or restaurants that serve halal food so that tourists do not have to worry anymore if you want to vacation to Bali."

Based on the results of these interviews can be seen that informants know about the existence of Ibnu Battuta Mosque in Puja Mandala Nusa Dua. Wenny initially worried it would be difficult to find halal culinary in Bali because the majority of the population is Hindu but it turns out now many places to eat or restaurants that serve halal culinary needed by Muslim tourists who visit Bali. In this episode Hamidah Rachmayanti as Host reminded that before eating the main menu it is better to eat fruit as an appetizer. It is based on Sunnah Rasulullah SAW. Although simple but the message delivered by the Host makes the audience can know and remember the Sunnah of Rasulullah SAW that may be forgotten. This is similar to the results of interviews with Alya (27), "Always like the halal living of many Islamic values like the Sunnah Rasulullah SAW that is often neglected, but by watching the halal living makes me recall the Sunnah of the Prophet who certainly has good values. Now before going to eat the main menu I definitely try to eat fruit that was good for digestion ".

On the Episode of Islamic Light in Tanah Sumba, the audiences are invited to see the natural beauty of Bukit Warinding, East Sumba. The expanse of Bukit Warinding signifies the greatness of Allah SWT. Although the majority of the population in Sumba is Christian, but Muslims can still build mosques. Al-Jihad Great Mosque is the Great Mosque located in Waingapu City. Al Jihad Great Mosque was founded on the surrounding communities that are not only Muslim but also Christian. This shows that although Islam is a minority religion in Sumba but still acceptable and can live harmoniously alongside other religions. This is similar to the results of interviews conducted by researchers, according to Rani (32) "Halal living episode of Light in Tanah Sumba, made me realize that life in Indonesia should be able to maintain a sense of tolerance. Islam is acceptable and live in harmony in a predominantly Christian area. It should be so with those of us who live in areas where the majority of Muslims should be able to help others despite their different beliefs. As did the Sumba community in building the Great Mosque of Al-Jihad. It turns out Sumba exotics stretch of nature is really cool, I became curious and interested to visit Sumba ".

In the episode of halal living entitled Build Ambon through Heka Leka, the audience is not only invited to enjoy the natural beauty and culture of the people in Ambon but 
also to know the Heka Leka community. Heka Leka is a community and also a social organization. Heka Leka is a social organization founded by Ambon youth to advance education in Maluku. Heka leka believes that change can only happen if there are people who want to move to seek the change. Bella Atamimi as Host of Halal Living volunteers in Heka Leka Goes to School which aims to educate the teachers in order to use the internet to facilitate the preparation of teaching materials. Heka Leka has a variety of programs including Maluku reading is by sharing books reading for the people of Maluku. In addition Heka Leka also formed a learning group for elementary school level up to junior high school that is a two hour movement for the future of Maluku. Based on the results of interviews conducted with Aya (28), "halal living not only provides information on halal tourism and culinary, fashion and beauty tips but also about the awareness of education. It made me realize that I had to do something to be useful for others. I was encouraged to donate a reading book organized by my office colleague. Alhamdulillah I can also provide compensation for orphans. Although the amount is not much but the important thing I intend to share as a form of gratitude for the blessings given to Allah SWT to me".

On the edition of Halal Tours of The City of Thousand Churches, provide information about the natural beauty of Lake Linow. Lake Linow is located in Tomohon, North Sulawesi. Tomohon is not far from the city of Manado to become a tourist destination that is in demand by tourists who visit Manado. Although the majority of North Sulawesi's population is Christian, the culinary served at the café in Lake Linow is halal. This is due to the large number of Muslim tourists who visit Lake Linow. Religious harmony in Tomohon can also be seen from Bukit Prayer or Bukit Kasih. In Bukit Kasih there is a monument which is a symbol of religious harmony. In the hill of love there is also a Church, Mosque, Temple, and Vihara built side by side. In this episode the Host gives tips mix and match casual outfit that can be used by the audience who will travel without leaving the trip of Islamic values. Based on the results of interviews with Wenny (30) "In addition to Bunaken marine park in Manado there is also a cool tourist destination that is Lake Linow. In Manado also many places that provide halal culinary so we don't have to worry if we want to visit to Manado. There is fried banana using sambal roa. Sambal roa is traditional sambal of Manado; really want to invite husband and children on vacation there.

Based on the results of interviews that researchers do then it can be known that the stimulus message delivered in the halal living both related to the natural charm and tourism potential, the history of the entry of Islam in the cities of Indonesia, fashion and health tips, and social awareness in the field of education is acceptable by the communicant who became informants in the study. Communications that occur can run if the communicant gives attention to the stimulus presented to him. Until the process of the communicant think about it so that arises understanding and acceptance or maybe vice versa. Attitude changes can occur in the form of cognitive, affective or behavioral changes.

According to Framanik (2012) the factors that influence the successful implementation of S-O-R theory:

a. Communicator

This is related to who gives stimulus; a communicator is required to have high credibility, adequate communication skills, and also the attraction that can attract the attention of the communicant. Communicators in Halal Living are programs that are Muslim Influencers Indonesia such as Hamidah Rachmayanti, Bella Atamimi, Aghnia Punjabi, and Gita Savitri. The Hosts not only have a beautiful face but also have achievements that can inspire millennial Muslim. Based on the interviews the 
informants acknowledge that the Host of the kosher living is the hijaber who look attractive. As Aya (28) said, "The host is very beautiful, very happy to see it. So the more confident and convinced that using hijab does not reduce the beauty but it is more beautiful ". The same thing is also said by Detti (26), "one of the reasons I often watch halal living is in addition to the beautiful host how to convey the information is also exciting to represent the style of young people who like to visit new places but still apply the values of Islam in everyday life". This is similar to the opinion of Permadi (2018) Halal Living not only stops at its very pretty host but also its neat and measurable packaging with the limitations of duration that make the viewer not to immediately switch the channel. In addition, between the titles of the event, the content, and the presentation are synchronized and combined in a sequence, concise and compact. Thus the hosts of kosher living can persuade and convince millennial Muslim to watch halal living. If the audience is interested in watching the halal living then the audience can obtain and apply information about tourism activities, kosher culinary, beauty tips and fashion provided.

b. Media

In order for messages or ideas can be easily accepted by the communicant then a communicator must be able to use the media in accordance with the characteristics of the communicant, it aims to facilitate the process of understanding. Media in this case is a channel from Net TV. Net TV is a channel of interest to young people. Net TV has current Television jargon. With this jargon the impressions provided by Net TV are expected to entertain and inspire viewers who are mostly young people. Viewers can not only watch via TV channels but can also access via YouTube so audiences do not worry about missing every episode of halal living. In addition, the audience segment of Net TV is millennial and middle up viewers. Halal living is an appropriate program to spread Islamic values to millennial Muslims. This is in accordance with the results of interviews with Aya (28), "Honestly if watching events like lectures or Islamic history it is very boring. If Halal living in addition to discussing about traveling, fashion, culinary, but also provide guidance that reminds me of the teachings of Islam. It was after watching halal living I want to apply Islamic values ". Based on these opinions can be seen that millennial Muslims will choose the media in accordance with the characteristics they have. According to Lyens (2004), mentions that generation $Y$ is a generation that grows on the internet boom. The target audience of Net TV is a millennial middle up besides Net TV also utilizes digital channels to be able to attract its market. This is in accordance with the statement from Wishnutama (2017) The digital era inevitably affects the presence of this television station. Tailored with a digital strategy, NET TV is emerging into the television industry by accommodating the new tastes of the Indonesian people for quality content of television program.

The quality of entertainment is synergized with the digital market through new platforms and distribution channels that make it easy to distribute NET TV-made content. "When NET was born, we have already proposed that it is not a regular television channel, but also an aggressive TV channel in digital. Digital presence NET TV largest in Indonesia with total reach 17,834 video. According to Wishnutama, digital NET TV activity is also the most "noisy" on Twitter and other social media than other television media. "Although viewed from followers there are still more than NET TV, but followers are not only seen from the numbers, but also the quality of the followers themselves. How they engage, have the power to buy, and have influence. Because our followers are verified accounts starting from the president, vice president, ministers and other important figures ". Based on this it is not surprising that millennial Muslims choose Net TV media as one of the favorite channels they watch. In addition to Net TV 
shows not only can be watched through television channels but can also be accessed via YouTube. Content from Net TV also has good quality.

c. Characteristics of communicant (Organism)

This factor determines whether the idea conveyed will be accepted or not, so the deepening of the communicant will allow the success rate of stimuli provided is very large. According to Wishnutama (2017) as CEO of NET TV, based on Nielsen's data, 45\% of millennial generations watch NET TV as their channel preference. In this case halal living is one of the segments that exist in the program Indonesia Morning Show (IMS) is a segment that contains information about tourist destinations, halal culinary, and fashion in it contain Islamic values so that focused on Muslim Millennial audience. This is in accordance with the characteristics of the informants in this study who are Muslim millennial or commonly called Y generation. According to Bencsik, Csikos and Juhez (2016), Generation Y is a generation born in 1980-1995. Lyons (2004), mentions that generation $\mathrm{Y}$ is a growing generation on the internet boom. Generation $\mathrm{Y}$ uses many instant communication technologies such as email, sms, instant messengers, and social media like facebook and twitter. Based on the results of research Lancaster and Stillman (2002), Y generation or millennial generation is a generation that has a realistic attitude. Generation Y greatly appreciates the difference, is oriented towards cooperation and is very pragmatic in solving solutions. In the Y generation workplace has a high sense of optimism, focus on achievement, confidence, trust in moral and social values, and appreciate diversity.

Relating to the characteristics of the millennial described by Lancaster and Stillman, the halal living episodes analyzed in this study are: a. Lombok's natural and cultural charm, b. Bali Friendly Muslim Tour, c. Islamic Light in Tanah Sumba, d. Building Ambon Through Heka Leka, and e. Halal City Tours The Thousand Churches of Manado provide information according to the needs of Muslim millennial who are generation who have a realistic attitude. The episodes in the halal living also present how Muslim communities from mostly non-Muslim regions can coexist and respect each other in accordance with the characteristics of millennial who deeply appreciate the differences. The episode to build Ambon through Heka Leka is also invited to contribute to give a change for the environment by following Heka Leka social movement to help society to more educate life of nation. This episode inspires the role of young leaders to motivate others to contribute in the field of education in various ways by providing books, training for teachers to use the internet to support teaching and learning activities, as well as providing free tutoring for students who cannot afford. This is in accordance with the characteristics of the millennial generation that is oriented towards cooperation and very pragmatic in solving solutions.

\section{CONCLUTION}

The information presented in halal living makes knowledge of Muslim millennial to be more aware of the existing tourist destinations in Indonesia, halal culinary, fashion hijab and other halal lifestyles that are in accordance with Islamic values.

Muslim millennial is driven to do positive things that can impact the environment.

Information about tourist destinations make Muslim Millennial know and interested in visiting these places.

Halal living became one of the media in spreading the value of Islam related to halal life style for Muslim millennial because the content of the halal living in accordance with the character and information needs of Muslim millennial Host (communicator) of halal living is a celebrity that is a Muslim influencer in Indonesia. This causes the message in halal living to be accepted by Muslim millennial because the communicator or Host of 
the Halal living is a Muslim Influencer. The media used is Net TV and YouTube so easily accessible by Muslim millennial.

Halal Living Impressions presents information about travel, culture, Islamic history, halal culinary, fashion, health and social awareness, all of which are halal lifestyle concept that can be applied in the daily life of Muslim millennial.

\section{REFERENCE}

[1] Bencsik, A., Csikos, G., Juhoz, T. (2016). Y and Z Generations at Workplaces. Journal Of Competitiveness, 90-106. https://doi.org/10.7441/joc.2016.03.06.

[2] Framanik, Naniek Aprilla. (2012). Communication Persuasion. Serang: Kocipta Publishing.

[3] Gitosudarmo, Indriyo \& Sudito, I, N., (1977). Organizational Behavior. First Edition, Cetakan Pertama, Yogyakarta: BPFE.

[4] Hariadi, S.S., (2011). Group Dynamics: Theory and Applications For The Analysis of Farmer Group successes as learning, cooperation, production, and Business. Yogyakarta: Graduate School UGM.

[5] Kriyantono, Rachmat. 2010. Practical Technique Of Communication Research. Jakarta: Kencana Prenada Media Group

[6] Lancaster, L.C. and Stillman, D. (2002). When Generations Collide Who They Are Why They Clash How To Solve The Generational Puzzle at Work. New York: Co.

[7] Lyons, S. (2004). An Exploration Of Generational Values in Life and At Work. ProQuest Dissertation and Theses, 441-441. Retrieved from http//ezproxy.um.edu.my/docview/3005203456?accountid=28930

[8] Notoatdmodjo, (1997). Public Health Science. Jakarta: Rineka Cipta.

[9] Tahmid, K. (2017). Halal Lifestyle. Majelis Ulama Indonesia Lampung. http://muilampung.or.id/2017/05/17/halal-life-style/ 